\title{
Genetically Targeted Fractionated Chemotherapy
}

\author{
Aaron J. Smith, John Oertle, Dino Prato* \\ Envita, Scottsdale, USA \\ Email: Aaron@envita.com, ${ }^{*}$ DinoPrato@Envita.com
}

Received 4 January 2015; accepted 10 February 2015; published 11 February 2015

Copyright (C) 2015 by authors and Scientific Research Publishing Inc.

This work is licensed under the Creative Commons Attribution International License (CC BY). http://creativecommons.org/licenses/by/4.0/

(c) (i) Open Access

\begin{abstract}
Complex and late stage cancer patients are in need of novel methods of selecting and administering chemotherapy particularly for those patients who are refractory to current treatment methods. The use of biomarkers to enhance decision making with regard to the molecular profile of a person's cancer is becoming more important in the practice of oncology. The standard for the last several decades is to elect chemotherapeutic agents based on staging and histological identification of the primary cancer site alone versus utilizing the genetic and molecular profile information along with histological primary cancer site and staging to select chemotherapy regimens. Cancers are caused by mutations that occur within cells and therefore selecting treatment based on mutations and not primary cancer site alone can provide advantages that may have gone overlooked. As time progresses, more biomarkers continue to be discovered which can lead to more targets for drugs either currently on the market or clinical trials. In addition to advancements made in the progression of cancer treatment with utilizing molecular profiles effectively, there are other therapeutic strategies that have been postulated as advanced effective ways to administer chemotherapy. These strategies provide chemotherapy to patients while fasting, giving insulin or other biological response modifiers adjunctively prior to chemotherapy for enhanced targeting, and giving chemotherapy in micro-doses to allow for increased frequency of administration and the utilization of multiple targeted chemotherapeutic agents concurrently. In this paper we will discuss these topics and explain their benefits in addition to the evidence that supports these treatments. A review on biomarkers and cancer cell metabolism is discussed as it relates to providing a framework for what constitutes a biomarker in addition to what metabolic processes are related to fasting and administering insulin with chemotherapy. The information provided in this document is designed to illuminate and provide evidence for various methodologies that are underserved in the treatment of cancer.
\end{abstract}

\section{Keywords}

Biomarkers, Molecular Profile, Cancer, Chemotherapy, Glycolysis, Insulin

\footnotetext{
${ }^{*}$ Corresponding author.
} 


\section{Introduction}

Advances in treating cancer have been blooming over the past decade, often predicated from breakthroughs in molecular genetics including the sequence of the human genome. With all of the advancements in cancer research, patients are becoming more optimistic even though the results of standard cancer treatments have not significantly improved. Out of a 1193 patient cohort with Stage IV cancer, about 69\% of patients with lung cancer and 81\% with colorectal cancer did not understand that chemotherapy is almost certainly ineffective for them [1]. New methodologies including the use of molecular profiles developed from the discovery of biomarkers and their associations with the selection of chemotherapies are starting to take flight in current cancer treatment. Although these methodologies are promising, the scientific community is still scrambling to find ways to improve the selection of drugs, deal with the complication of drug approval process, in addition to creating new novel forms for the treatment of cancer and making them available to the much needed patient base that is often not given good viable options to improve and extend life and quality of life.

The biology of cancer is complex and should be considered in a case by case basis with regard to treatment. Cancer treatments should be as unique as the individual that is being treated. However, there are strategies a physician can implement to enhance the therapeutic benefit of chemotherapy. The most common is to use molecular profiles to improve selection of chemotherapeutic agents and target specific known physiological characteristics of cancer through selecting proper chemotherapy administration techniques.

In this paper, a background of biomarkers and cancer cellular metabolism with an emphasis on the effect of insulin on cancer treatment is used to enhance an understanding of cancer treatment in addition to listing suggested drugs to target biomarkers or stages of the cell cycle. This work is not exhausted particularly since studies demonstrating enhancement of chemotherapy using insulin shows promise in vivo and in vitro studies but has not gone much further in recent clinical investigations. In addition a case is made for why adjunctive insulin shuttling deserves further analysis with particular regard to its effect on cancer cell cycle, its potential to enhance drug delivery that targets specific stages of the cell cycle, and potentially enhances cell membrane permeability which may allow for fractionation of multiple agents. This paper also does not exhaust all the potential genetic, biomarkers, and molecular profiles available for cancer treatment; however, a list of particular agents with some background on the selection of biomarkers is provided.

\subsection{Biomarkers}

Biomarkers are molecular signatures that have characteristics identified by the levels or activities of genes, and other features associated with the cell. These biomarkers are either objective measures or something that is associated with the evaluation of biological processes or pharmacological reactions to intervention by therapeutics [2]. They also include measures of a person's health by diagnostic testing and imaging technologies. Biomarkers show promise in aiding therapeutic decision making in addition to drug metabolism, safety, and efficacy.

By the year 2020 there is expected to be 16 million new cases of cancer [3]. Cancer itself is a myriad of alterations of genes with regard to mutation and expression that causes uncontrolled proliferation to both somatic and germ cells [4]. The three major classes associated with oncogenesis include proto-oncogens, tumor suppressor genes, and DNA repair. Epigenetic changes can also occur in normal cells that contribute to oncogenesis largely by DNA methylation and unusual patterns associated with histone modifications.

Establishment of biomarkers in cancer involves comprehending molecular and cellular mechanisms that are associated with the initiation of cancer by focusing on changes in regulatory genes or proteins. Although it is challenging at times to ascertain this information and relate it to clinical oncology, applying the information to guide therapeutics that target biomarkers is possible. First, diagnostic and prognostic biomarkers must be established to predict who is at risk and also to diagnose at an early stage. The selection of best treatment from this information must also be monitored closely to understand the response of the treatment [5]. Cancer diagnostics associated with biomarkers can involve radiological findings to include overall metastatic spread like those seen in PET scans in addition to detection of circulating oncogenic antigens like prostate specific antigens among many other tumor markers. Genomic information gathered from next generation DNA sequencing, microarrays, and mass spectroscopy offer a plethora of potential biomarkers. However, biomarkers are not limited to genomics. Information regarding a cancers transcriptome, proteome, and even the metabolome can be processed in tandem. 


\subsection{Cellular Biomarkers}

Circulating tumor cells (CTCs) in advanced stages of cancer and immune cells can serve as biomarkers for prognosis in addition to evaluating the cancer progression or effectiveness of therapy. CTCs provide an indication of the progression of the cancer where an increased number of CTCs indicate progression while a decrease in CTCs point to the effectiveness of the treatment [6] [7]. The effectiveness of a cancer treatment can be assessed by the number of CTCs even after the first cycle of therapy. It is important to note that the elimination of CTCs is an important benchmark but it does not go as far as indicating the removal of all cancerous cells. Fresh CTCs cultures may also have mutations that were not found in the tumor especially if the biomarkers for the tumor were extracted months or even years prior to discovering or analyzing biomarkers associated with CTCs. T-regulatory cells (T-regs) can be used as an indicator of poor immune response to cancer and even tumor growth when there is a high count of T-regs circulating [8] [9]. Lung, pancreatic, breast, liver, and skin cancer patients have been known to have high levels of T-regs either circulating or within the tumor itself [8] [10]-[13]. It is important to note that high levels of T-reg cells may also be an indication of an infection [14].

\subsection{Chromosome Based Biomarkers}

It has been well established that aberrant changes in the structure or even numerical aberrations can cause neoplastic transformation. Malignant tumors have been found to include hyper-, hypo-, and aneuploidy derivations from deviations in from diploid chromosomes [15]. Overexpression of genes has also been documented in malignant cells, which can also be used to serve as biomarkers [16]. Promising biomarkers found in malignant transformation can include somatic mutations and aid in assessing cancer risk [15]. Cancer risk can often be assessed by polymorphisms in particular genes [17] [18]. Transcriptomes of neoplasms can also be used to identify (most prominently cancers predicated by epithelial tissue) cancers in the blood [19] [20]. Flow cytometry can be used to measure the proliferation status of cells and in particular cancer cells. Histological analysis can complement work done by flow cytometry by identifying and analyzing the clonal and special heterogeneity of malignant tumors [21]. Other molecular biologic techniques can also be used to determine whether or not a cell is rapidly multiplying by or more specifically, identify the number of cells in the $\mathrm{S}$ phase.

\subsection{Genetic Biomarkers}

Cancer is after all a genetic disease where alterations in genes including oncogenes and tumor suppressor genes affect the cells proliferation rate and overall survival. This occurs by either a gain or a loss in function associated with oncogenic transformation. Some of these genes can transform to a gene with oncogenic potential by as little as a point mutation. Certain nonrandom mutations are known to cause specific kinds of cancers. Gene deletions are also very important to consider especially if the gene deletion is associated with a tumor suppressor gene. Such deletions can be detected using PCR microsatalite probes on various chromosomes. However, it is important to note that random chromosomal abnormalities can also influence morphological changes associated with various cancers. Microsatalite instability can be detected via comparison to noncancerous cells for early detection of cancer [22] in addition to aiding decision making associated with prognosis and evaluation chemotherapy [23]. Mutations that deactivate adenomatous polyposis coli (APC) genes are extremely common in oesophageal adenocarcinoma and squamous cell carcinoma of the oesophagus since APC is an important player in the suppression of cancer [24]. Deactivation of APC is also very common in colorectal carcinoma and can lead to polyps that have the potential to become cancerous [25]. The commonality of mutations in APC genes and its association with cancer is why APC is a common biomarker for various cancers. Detection of these mutations is most commonly derived by PCR based tests.

\subsection{Epigenetic Biomarkers}

Epigenetic modifications alter the gene expression within both noncancerous and cancerous cells. Such modifications have the potential to alter the expression of various genes including tumor suppressor genes. Such modifications are most commonly associated with methylation of oligonucleotides or by methylating, acetylating, or phosphorylating histones which winds the DNA and in term affect the expression of genes [6]. DNA methylation occurs on cytosine bases as is the predominate form of DNA augmentation in humans [26]. Both DNA hyper- and hypo-methylation are associated with important events in either cancer initiation or progression. The activity of 
DNA methyltranferase can be altered as a result of genetic events associated with mutation. Such mutations can lead to aberrant fluxes in gene regulation respectively that can cause genetic instability and in the case of hypomethylation can lead to stronger gene expression [27]. It is also important to note that hyper-methylation has the opposite effect with regard to gene regulation; specifically with regard to silencing tumor suppressor genes that has a similar effect as a mutation would with regard to oncogenesis. Genes associated with control of the cell cycle and apoptosis have the potential to be shut down by hyper-methylation. Cell cycle control and apoptosis involve a plethora of genes that if shut down could lead to various cancers. Detection of hyper-methylation as a biomarker can be used to predict whether a cancer is likely to become recurrent and even the cancer's likelihood of becoming metastatic. In the case of lung cancer, hyper-methylation of the cells found in sputum has potential to act as a noninvasive early warning of a smoker's likelihood of developing lung cancer. O6-methylguanine-DNA methyltransferase (MGMT) gene methylation signals resistance to alkylating agents but also can signal that the silencing of this gene in malignant glioma cells will respond better to therapy [18]. Although treatment of epigenetic disorders in cancer may involve the use of drugs that reverse DNA methylation and histone acetylation, particularly in lymphoma and leukemia drug therapy, the options for treating epigenetic causes of cancer are still very limited.

\subsection{Cancer Antigens as Biomarkers}

In the previous sections we have focused on the genome and the epigenome as biomarkers of cancer. The proteome itself is involved in virtually every cellular process that occurs in cancer cells, the tumor microenvironment, in addition to how cancer interacts with noncancerous cells. Cancer cells are known for secreting proteins and other macromolecules which can be used as biomarkers. There are a vast array of diverse antigen based biomarkers in a single cancer type that can be multiplied by the number of unique cancer cells. Much like the genomic analysis associated with biomarkers, there are too many antigenic biomarkers to discuss in one paper. In addition to antigens of the cancer cell itself, antibodies can be used to determine whether its compliment is found somewhere in the body. Proteomic analysis is not limited to proteins excreted from cancer cells or even on the cell surface since there are many enzymes and proteins that are found in excess within cancer cells. Although high levels of heat shock protein (HSP) are indicative of cancer cells, the high levels themselves cannot be used for diagnostics. Also, high levels of insulin receptors are common among cancer cells, particularly due to the Warburg effect. Excess insulin receptors, like HSP, cannot be used for diagnostics.

\subsection{Metabolic Biomarkers}

Glucose metabolism, with an emphasis on the Warburg effect, can be used as a biomarker. This mechanism involving the shift from oxidative phosphorylation to glycolosis requires more glucose to produce ATP, particularly for rapidly growing cells like cancer. For these reasons, a bioenergetic index of the cell (BEC) has the potential to for both the classification, prognosis, and the cancer cells response to various therapy [28]. Glucose analogs labeled with Fluorine 18 can be used in conjunction with positron emission tomography (PET) to localize regions where a tumor is growing inside the body [29]. FDG-PET can be used to determine the extent of which glucose is being metabolized in a cancer cell which correlates to the extent of the cancer's malignancy where high glucose metabolism is related to a worse prognosis [30]. The process involves the administration of radiolabeled glucose that can be picked up to view specific regions in the body where cancer is present. A reduction in the amount of glucose a cancer cell is taking up after treatment with chemotherapy is an indicator of a positive outcome for the patient [31] [32]. For this reason, the cancer's utilization of glucose can be used as a metabolic biomarker in the diagnosis, prognosis, and to the response that tumors have when exposed to chemotherapy [33].

\section{Molecular Profiling and Selection of Chemotherapy}

Molecular profiling is essentially the culmination of characteristics associated with multiple biomarkers associated with either the individual or the cancer itself. The biomarkers included in molecular profiles often involve genomic, epigenomics, and proteomics typically associated with a disease including cancer. Molecular profiles of cancer are available commercially for cancer types in order to enhance the use of chemotherapy by listing possible drugs and their drug targets associated with various biomarkers. These companies often use different protocols, machines, total number of targets in addition to different targets. These companies may also suggest different treatments for a particular biomarker associated with cancer. Although the field of molecular profiling and 
competition is growing rapidly, the effect of having the molecular profiles of patients is still relatively new but very promising.

Drug selection is made easier with molecular profiling (Table 1). Previously, and to an extent presently, cancers were partitioned into categories and subcategories involving anatomic site of origin, clinical behavior, and histopathological appearance [34]. To this day, clinical trials are conducted on patients based on their categories and subcategories of cancers rather than clinical trials on their molecular profiling; therefore the drugs are administered on patients based on superficial reasons where only a fraction of the population responds to the drug. This has led to physicians administering chemotherapy with a marginal rate of success to patients that are not likely to respond well to the treatment. Tragically this has led to many patients being treated with toxic drugs that cause severe side effects with little tumor response.

Table 1. The following is a list of drugs that have a greater likelihood of working in the presence of a particular biomarker as an example of how a physician might make a decision in the selection process.

\begin{tabular}{|c|c|c|}
\hline Agents & Tests & Reference \\
\hline $\begin{array}{c}\text { Tamoxifen, } \\
\text { Toremifene, } \\
\text { Fulvestrant, } \\
\text { Letrozole, } \\
\text { Anastrozole, } \\
\text { Exemestane, } \\
\text { Megestrol Acetate, } \\
\text { Leuprolide, and Goserelin }\end{array}$ & ER & [35]-[41] [44] [45] \\
\hline \multirow[t]{3}{*}{ Fluorouracil, Capecitabine, and Pemetrexed } & TS & [46]-[48] \\
\hline & PGP & [49] [50] \\
\hline & SPARC Monoclonal & {$[51][52]$} \\
\hline \multirow[t]{3}{*}{ Paclitaxel, Docetaxel, and Nab-Paclitaxel } & SPARC Polyclonal & {$[51][52]$} \\
\hline & TUBB 3 & [53]-[56] \\
\hline & TLE3 & [57] \\
\hline Gemcitabine & RRM1 & [58] \\
\hline \multirow[t]{2}{*}{ Irinotecan } & TOPO1 & [59]-[61] \\
\hline & ER & [62]-[64] \\
\hline \multirow[t]{3}{*}{ Everolimus and Temsirolimus } & Her2/Neu & {$[61][63]-[65]$} \\
\hline & PIK3CA & [66]-[68] \\
\hline & c-KIT & [69] [70] \\
\hline Imatinib & PDGFRA & [71]-[73] \\
\hline \multirow[t]{2}{*}{ Vandetanib } & RET & [74] \\
\hline & Her2/Neu & {$[75][76]$} \\
\hline \multirow[t]{2}{*}{ Doxorubicin, Liposomal-Doxorubicin, and Epirubicin } & PGP & [77] [78] \\
\hline & TOP2A & [79] [80] \\
\hline Erlotinib and Gefitibib & PTEN & [81] \\
\hline Trastuzumab, Pertuzumab, and Ado-trastuzumab Emtansine (T-DM1) & Her2/Neu & [62] [82]-[87] \\
\hline Lapatinib & Her2/Neu & [88]-[90] \\
\hline \multirow[t]{2}{*}{ Temozolomide and dacarbazine } & MGMT & [91] [92] \\
\hline & PGP & [49] [50] \\
\hline \multirow[t]{2}{*}{ Docetaxel and Paclitaxel } & TLE3 & [57] \\
\hline & TUBB 3 & [53]-[56] \\
\hline
\end{tabular}


Selection of biomarkers should target biomarkers that the cancer may be "addicted” to. Although a molecular profile can reveal a plethora of biomarkers that could be used in conjunction with chemotherapy, the biomarkers are not alike. Some targets are far more necessary for the cancer's growth and survival than others. It is also important to note that some chemotherapies target the mode of the mutation by targeting mechanisms associated with an increased rate of mutation and although the cancer may not be addicted to the mutation, it is an important target for reducing the likelihood of further metastasis.

\subsection{Biochemistry of Normal and Cancer Cells}

The biochemistry of normal resting cells energy demand relies typically from glucose entering glycolysis, where it transformed into pyruvate, which is then oxidized to become ATP. During normoxic conditions, a single glucose molecule is oxidized in glycolysis and becomes two molecules of pyruvate before entering the mitochondria. This is where pyruvate is decarboxylated by pyruvate dehydrogenase (PDH) to become acetyl-CoA which enters the TCA cycle. Under these normoxic conditions, 36 ATP molecules are created with respect to only one molecule of glucose. However, in conditions of hypoxia and anoxia, the cell has the capacity to generate two ATP molecules by respectively diverting pyruvate away from oxidative phosphorylation. In this biochemical pathway, one glucose molecule will still produce two molecules of pyruvate. However, unlike the aforementioned pathway of oxidative phosphorylation, the pyruvate is converted into lactate by lactate dehydrogenase (LDH) within the cytosol and will result in the formation of only two ATP molecules. This process also creates additional NAD+ which is essential for glycolysis.

When cells transform to rapidly growing malignant tumor cells the demand for energy changes with regard to its biosynthetic precursors. This change involves a switch from oxidative phosphorylation, which occurs at a lower rate and is associated with the oxidation of pyruvate via the TCA cycle, to a higher rate of glycolysis and lactic acid production. This process occurs in aerobic conditions and is associated with high glycolytic rate in addition to high glucose dependency. This phenomenon is known as the Warburg effect named after Otto Warburg [93]. He presented evidence suggesting that cancer cells produce lactate from glucose under normoxic conditions [93]-[95]. The Warburg effect should not be confused with his work in photosynthesis where Warburg and colleagues described the inhibitory effects of $\mathrm{O}_{2}$ on photosynthesis where $\mathrm{O}_{2}$ is a competitive inhibitor of $\mathrm{CO}_{2}$ during carbon fixation in addition to the effect of $\mathrm{O}_{2}$ on photorespiration [96], which is also known as the Warburg effect.

There are two pathways for cytosolic pyruvate generated by glycolysis depending on whether the cells are in aerobic or anaerobic conditions. The first pathway comes from aerobic conditions where pyruvate is taken up by the mitochondria and enters Kreb’s cycle. During anaerobic or hypoxia conditions, much like what occurs in during muscle contractions, pyruvate does not have the capacity to be oxidized further due to lack of available oxygen. This results in pyruvate being reduced to form lactate. Rapidly growing cancer cells use the latter approach and in turn become more dependent on the consumption of glucose. The high glycolytic rate in which cancer cells consume glucose during the Warburg effect meets the requirements for rapid cell division with its association in the production of nucleotides and amino acids. Acetyl CoA is also produced through ATP citrate lyase (ACL) in the cytosol and is associated with the production of fatty acids for cellular membranes.

\subsection{Effect of Fasting on Cancer Development}

Cancer cells that are not capable of retrieving key nutrients like glucose have been experimented in animal studies and in vitro have an effect on cancer cell growth. Cycles of starvation have been shown to be as effective as chemotherapeutic agents in reducing or delaying the progression of tumors [97]. Fasting also increases the effectiveness of various drugs associated with glioma, breast cancer cells, and melanoma [97]. The fasting in multiple cycles enhance differential stress sensitizing in various tumors which has the potential to augment or replace the effectiveness of some chemotherapies in the treatment of a variety of cancers [97].

\subsection{Insulin Receptor}

Cancer cells obtain glucose much the same way as other cells in the human body; just more of it. A significant amount of attention to the manner of which glucose enters the cell begins with insulin and insulin receptor (IR) or insulin and IGF1 receptor (IGF1R) binding. The binding of insulin to either one of these receptors initiates a complex cascade of biochemical reactions which eventually leads to the induction of GLUT4, intercellular translocation of GLUT 4 to the plasma membrane [98] [99], and the channel for which GLUT4 allows glucose to 
enter the cell.

In cancer cells, the deregulation of expression of Insulin Growth Factor 1 Receptor (IGF1R) may have a role in cancer progression in addition to resistance of treatment. Insulin Receptors (IRs) are also overexpressed in malignant cells that can either reach or exceed physiological expression levels compared to liver or adipose tissue [100] [101]. Various mechanisms that include splicing alterations of the IR isoform A causes an increase in binding affinity for IGF, thus altering the functional specificity of the IR signaling in the presence of insulin.

As mentioned above, GLUT 4 translocation is triggered by the binding of insulin to the IR. However, other biochemical effects are initiated by the binding of insulin to IR. The cascade of biochemical interactions includes the primary cascade involving the PI3K signaling pathway. In addition to that pathway, the activation of MAPK cascade associated with the mitogenic effects in addition to mediating cellular proliferation and respectively survival are both associated with the mTOR/p70S6K pathway which is also associated with cellular survival, cell growth, and metabolism. It is important to note that different cells use different pathways to proliferate and some pathways are used in particular cancer cells more than others; particularly in different stages of development. This underlines cells ability to preferentially activate specific signals depending on many variables that affect the overall metabolic and mitogenic effect of IR. It is also important to highlight that these metabolic pathways interact with each other which makes the IR signaling even more complex.

\subsection{Cancer Cell Cycle}

A critical regulator of the cellular proliferation and growth in addition to cellular division after damaged DNA is the cell cycle. The cell cycle respectively controls the transition from quiescence (G0) to cellular proliferation. It accomplishes this through various checkpoints to ensure the fidelity transcription. The mechanism itself involves four phases including the DNA synthesis or the $\mathrm{S}$ phase, Mitosis also known as the M phase, and the G1 and G2 phases. CDKs complex with cyclins are the driving force between phases of the cell cycle. It is important to note that there are inhibitory proteins known as CDK inhibitors that are negative regulators of the cell cycle and essentially prevent the cell from proceeding from one step to the next. Cyclin expression varies in a manner that expression patterns of the cyclins and their relative intracellular location is associated with the cell cycle [102] [103]. Of these CDKs, CDK1-CDK9 has been identified but some of these CDKs roles' have not been clearly defined. Activation of CDK/cyclin complexes by phosphorylation on specific sites on the CDK by cdk7/cyclin $\mathrm{H}$ is an important step in the initiation of the cell cycle progression [104].

\subsection{Cell Cycle}

Using drugs to target cancer cells during various stages in the cell cycle is often based off of the arrest of CDK by inhibition that has the potential to induce apoptosis. The majority of oncogenes and tumors-suppressor genes are components of a signal transduction pathway that are involved or controls various cellular functions associated with cell cycle entry or exit [105] [106]. Loss of checkpoint integrity is a driving force regarding why tumor cells are unable to stop during specific points of the cell cycle. This can either be caused by overexpression of cyclins or the inactivation of CDKs. CDK inhibitors are novel cancer agents that inhibit CDKs by targeting the catalytic subunit or by targeting regulatory pathways that are associated with CDK activity [107]. A significant amount of work has gone toward the inhibition of transcription in tumor cells.

\subsection{Insulin and Cell Cycle Progression}

Breast cancer cells and normal mammary cells in culture can both be induced by the mitogen insulin for cellular growth [108]-[110]. Breast cancer cells often overexpress insulin receptors [111] [112] which can affect the phenotype of mammary epithelial cells [113] [114]. Down regulation of insulin receptor cells does not occur within high concentrations of insulin in breast cancer cells [115] [116]. Insulin receptor-positive breast cancer carries a worse prognosis than those with insulin-negative breast cancer tumors [117]. Potentiation of cancer cells grown in $\mathrm{L}$ - $\alpha$-lysophosphatidic acid (LPA) in the presence of insulin induces the cellular cycle via the Rho-A-dependent activation of cyclin E of MCF-7 breast cancer cells [118]. Insulin enhanced growth is likely caused by the intracellular PI 3 kinase pathway [118]. 


\subsection{Drugs Targeting Cell Cycle}

Cancer is characterized by its abnormal and often uncontrolled growth. The mechanism for chemotherapeutics used to combat cancer involves stopping the replication of the cancer cells. Therefore, it is important to keep in consideration the cell cycle of cancer when selecting a chemotherapeutic.

Chemotherapeutic drugs are often injected into the bloodstream where the drug circulates throughout the body before reaching cells that are actively dividing. It is important to note that not all tumor cells are in the same stage of cellular replication. Some of these cancer cells are in the resting phase where certain chemotherapies are unable to destroy them. This is one of the reasons why chemotherapy is often given in cycles.

There are two predominant classes of chemotherapy which include cell cycle specific or cell cycle nonspecific chemotherapy. This means that cell cycle specific drugs only work at certain phases of the cell cycle while cell cycle nonspecific drugs can attack cancer at either resting phase or when the cell is actively dividing (Table 2). Cell cycle nonspecific includes alkylating agents, nitrosureas, and non-cytotoxic drugs including hormone and steroid drugs. Cell cycle nonspecific drugs are often given in a single bolus injection [119]. Conversely cell cycle specific drugs can plateau with regard to its cell killing ability. Cell cycle specific drugs include antimetabolites, vincaplant alkaloids, and other agents. These drugs are administered in minimized concentrations by continuous dosing method [119].

\subsection{Methotrexate and Insulin}

Insulin increases the potentiation of methotrexate [121]. However, the mechanism for the potentiation increase of methotrexate with insulin is unknown. Estradiol was used as a control [121] to see if mitogenic effects were responsible for the mode of action for the potentiation of methotrexate since estradiol stimulates DNA synthesis and cell growth [122]. The results of estradiol in potentiation of methotrexate came back negative which suggest another mechanism of action with regard to potentiation of methotrexate [121]. There have been a few hypothesis for the mechanism of increased potentiation of methotrexate to insulin. One of which describes the effect on insulin with regard to phospholipid synthesis associated with cellular membrane formation [123]. Since insulin is known to stimulate membrane synthesis associated with the increase in the formation of fatty acids, it is possible that the effect of insulin increase the overall permeability of the cellular membrane. Membrane fluidity by the introduction of insulin has been shown in rat adipocytes prior to membrane purification [124].

Table 2. Cell cycle specific drugs can be broken down into phases where certain drugs work best at certain phases of the cell cycle.

\begin{tabular}{ccc}
\hline S Phase & M Phase & G2 Phase \\
\hline Antimetabolites & Vinblastine & Bleomycin \\
Capecotabone & Vincristine & Irinotecan \\
Cytarabine & Vinoretbine & Mitoxantrone \\
Doxorubicin & Etoposide & Topotecan \\
Fludarabine & Teniposide & G1 Phase \\
Floxuridine & Docetaxel & Asparaginase \\
Fluorouracil & Paclitaxel & Corticosteroids \\
Gemcitabine & & \\
Hydroyurea & & \\
Mercaptopurine & & \\
Methotrexate & & \\
Prednisone & & \\
Procarbazine & & \\
Thloguanine & & \\
\hline
\end{tabular}




\subsection{Ellipticine and Insulin}

The process of nucleolar RNA processing of $45 \mathrm{~S}$ into other species in the sequence of ribosomal RNA maturation is an essential house-keeping gene [125]. The initiation of DNA synthesis and the completion of G2 phase is inhibited by elliptocin with exception to cells that are already in the S phase when exposed to the drug [126]. Similar alkaloids are known to break DNA [127] in addition to fostering chromosomal aberrations [128]. This is because these kind of drugs are intercalating agents for nucleic acid [129] [130]. Eliptosin potentiation by insulin is postulated to involve insulin stimulation of intermediary metabolic pathways which may cause an intracellular build-up of both pyruvic acids and lactic acid in addition to $\mathrm{CO}_{2}$ [131]. The mechanism is in addition to the potential that modulation of membrane via insulin increases drug transport into the cell.

\subsection{Doxorubicin and Insulin}

Anorexia during chemotherapy is a major complication to chemotherapy treatment [132]. Dietary supplementation and other routes of administering nutritional needs have not improved outcomes of cachexia [133]. During experimentation with insulin as a means to treat cachexia induced from chemotherapy, a significantly better prognosis occurred with treating patients with insulin and chemotherapy. A significant change in tumor growth was seen when comparing doxorubicin with doxorubicin with insulin, suggesting its ability to potentiate doxorubicin [134]. Doxorubicin inhibits DNA synthesis by binding to DNA as the primary mechanism for antitumor activity [135]. This means that cells in Go phase are resistant to the activity of doxorubicin. The mechanism for which insulin potentiates doxorubicin is unknown but it has been postulated to increase the rate of the cell cycle, allowing doxorubicin to inhibit the process of cellular growth.

\subsection{Membrane Permeability to Glucose}

Experimentation, with regard to the permeability of glucose across a cellular membrane with and without the presence of insulin, has been presented in a manner that controls for action associated with active transport of glucose by GLUT-4 associated with stimulation of Insulin receptor sites by insulin by using liposomes comprised of phosphatidyl choline bimolecular membranes [136]. In this study, the initial glucose permeability without the presence of insulin was several orders of magnitude lower than that of glucose permeability of glucose in red blood cells [136]. The liposomes permeability to glucose increased by $150 \%$ in the presence of insulin [136]. The glucose permeation rate also increased two fold compared to the insulin negative control. As another control, there is no increase in glucose permeability when insulin is within the liposome [136]. Comparison between liposomes and lipid membranes cannot be readily made, however, this research suggests that insulin may alter the permeability of a lipid bilayer in a similar manner.

\section{Discussion}

The ability to delineate which drug can be used during chemotherapy from the analysis of molecular profiles through biomarkers is a significant improvement from the conventional method associated with treating the cancer by type and subtype; however, depending on the medication selected, one has the potential to further enhance the effects of cancer treatment by various factors. If the target of the chemotherapy is on a particular phase of the cancer cell cycle and is in good standing with its molecular profile, we postulate that adjunctive insulin shuttling of chemotherapy with fasting as a biological response modifier may increase the overall benefit of the drug. Other evidence points to an increase in the cell's permeability in the presence of insulin. Although significantly more research needs to be conducted to differentiate between permeability due to active transport and membrane permeability, there is a potential to use insulin as a means of allowing certain drugs to pass through the membrane better than just chemotherapy alone.

Research regarding the increased permeability of glucose in liposomes in the presence of insulin is intriguing. Since the discovery of the GLUT 4 channel and its association with insulin, researchers began to focus on mechanisms associated with that relationship and stopped pursuing membrane permeability in the presence of insulin. One way that researchers might be able to discover the extent of membrane permeability in the presence of insulin would be to construct inverted membrane vesicles (IMV) and monitor changes in glucose flux across the membrane. This would eliminate the function of the insulin receptor since it would be pointed inward under these circumstances. Data collected from this kind of experiment could be compared with previous experimentation 
using liposome bilayers and offer more conclusive evidence of membrane permeability in the presence of insulin.

With the more refined method of selecting chemotherapy from the use of molecular profiles and their association with biomarkers, there is potential that the dosage required for the treatment of cancer to be reduced or even coupled with other chemotherapies to be administered at the same time could be possible and maximize patient outcomes. This may especially be the case in the presence of adjunctive insulin shuttling of chemotherapies in addition to fasting before chemotherapy administration. These approaches would be significantly less toxic to the patient in addition to the treatment being less detrimental to the immune system which plays a role in the regulation of cancer.

The current method of selecting new chemotherapies through various clinical phases is outdated when compared with adding the current understanding of biomarkers. A group and subgroup of cancers, like non-small cell lung cancer, is not enough to distinguish between the vast array different individualized non-small cell lung cancers with regard to molecular profiling associated with the cancer's biomarkers. We postulate that clinical trials for various cancers should be investigated on a personalized basis considering the patient's molecular profile. A better understanding of why chemotherapy and other cancer treatments work better with some patients more than others might allow an additional step in the process to hone in on patients with similar molecular profiles and biomarkers to be added to the study. While we are not arguing that there is no benefit from clinical trials to be conducted in its current form, it is important to take the selection of patients that did respond to a new chemotherapy to be analyzed by big data associated with bioinformatics to determine which biomarkers or the molecular profile as a whole contributed to the success of that chemotherapy.

There are currently many companies and clinical researchers going back to determine when a drug should be administered using molecular profiling after the drug has been on the market for a certain matter of time. The amount of research with regard to combining chemotherapies at once is limited. When ordering a molecular profile for a patient with cancer, one will notice that there are several drugs that have the potential to inhibit or kill the cancer. We believe that more work needs to be done in the area, however, utilization of molecular profiles in combination with adjunctive insulin shuttling is promising and may be used for better selection of targeted agents and better overall delivery of those agents providing variety of important options for patients that have been refractory to previous treatment.

\section{Conclusion}

There are a number of patients failing cancer treatments with late stage complex cancers where the standard methods of administration of drugs and chemotherapy are insufficient. Many patients are recommended hospice, palliative care and singular experimental treatment as their last option for treatment of cancer. Advances in the understanding of cancer biology through genomic, epigenomics, transcriptomics, proteomics, and metabolomics in the past decade usher in a new era of data collection and analysis. Such data can be used to better select and administer treatment options for cancer via molecular profiles and their associated biomarkers. Treatment options for patients have never been so prevalent despite the standard practice of practitioner's using tissue biopsies and staging as the primary methods for selecting treatment of cancer. Other treatment options including fasting and the use of insulin to enhance cell cycle selection in concert with genetically targeted fractionated chemotherapy, which can offer the opportunity to use more chemotherapies at once, were examined and discussed as a method to potentially fulfil the need of many patients that are resistant to chemotherapy using traditional conventional medicine. These treatment options were supported by relevant data and highlight an opportunity to invite researchers and other medical practitioners to consider treatment options that are beginning to gain momentum in the practice of medicine.

\section{References}

[1] Weeks, J.C., Catalano, P.J., Cronin, A., Finkelman, M.D., Mack, J.W., Keating, N.L. and Schrag, D. (2012) Pateints’ Expectation about Effects of Chemotherapy for Advanced Cancer. The New England Journal of Medicine, 367, 16161625. http://dx.doi.org/10.1056/NEJMoa1204410

[2] Srinivas, P.R., Kramer, B.S. and Srivastava, S. (2001) Trends in Biomarker Research for Cancer Detection. The Lancet Oncology, 2, 698-704. http://dx.doi.org/10.1016/S1470-2045(01)00560-5

[3] Cho, W.S.C. (2007) Contribution of Oncoproteomics to Cancer Biomarker Discovery. Molecular Cancer, $6,25$. http://dx.doi.org/10.1186/1476-4598-6-25 
[4] Hanahan, D. and Weinberg, R.A. (2000) The Hallmarks of Cancer. Cell, 100, 57-70. http://dx.doi.org/10.1016/S0092-8674(00)81683-9

[5] Ludwig, J.A. and John, N. (2005) Weinstein Biomarkers in Cancer Staging, Prognosis and Treatment Selection. Nature Reviews Cancer, 5, 845-856. http://dx.doi.org/10.1038/nrc1739

[6] Egger, G., Liang, G., Aparicio, A. and Jones, P.A. (2004) Epigenetics in Human Disease and Prospects for Epigenetic Therapy. Nature, 429, 457-463. http://dx.doi.org/10.1038/nature02625

[7] Cristofanilli, M., Budd, G.T., Ellis, M.J., Stopeck, A., Matera, J., Miller, M.C., et al. (2005) Presence of Circulating Tumor Cells (CTC) in Metastatic Breast Cancer (MBC) Predicts Rapid Progression and Poor Prognosis. Journal of Clinical Oncology, 23, 524.

[8] Liyanage, U.K., Moore, T.T., Joo, H.-G., Tanaka, Y., Herrmann, V., Doherty, G., et al. (2002) Prevalence of Regulatory T Cells Is Increased in Peripheral Blood and Tumor Microenvironment of Patients with Pancreas or Breast Adenocarcinoma. Journal of Immunology, 169, 2756-2761. http://dx.doi.org/10.4049/jimmunol.169.5.2756

[9] Siddiqui, S.A., Frigola, X., Bonne-Annee, S., Mercader, M., Kuntz, S.M., Krambeck, A.E., et al. (2007) Tumor-Infiltrating Foxp3 ${ }^{-} \mathrm{CD}^{+}{ }^{+} \mathrm{CD} 25^{+} \mathrm{T}$ Cells Predict Poor Survival in Renal Cell Carcinoma. Clinical Cancer Research, 13, 2075-2081. http://dx.doi.org/10.1158/1078-0432.CCR-06-2139

[10] Woo, E.Y., Yeh, H., Chu, C.S., Schlienger, K., Carroll, R.G., Riley, J.L., et al. (2002) Regulatory T Cells from Lung Cancer Patients Directly Inhibit Autologous T Cell Proliferation. Journal of Immunology, 168, 4272-4276. http://dx.doi.org/10.4049/jimmunol.168.9.4272

[11] Wolf, A.M., Wolf, D., Steurer, M., Gastl, G., Gunsilius, E. and Grubeck-Loebenstein, B. (2003) Increase of Regulatory T Cells in the Peripheral Blood of Cancer Patients. Clinical Cancer Research, 9, 606-612.

[12] Viguier, M., Lemaître, F., Verola, O., Cho, M.S., Gorochov, G., Dubertret, L., et al. (2004) Foxp3 Expressing CD4 ${ }^{+}$CD25 $5^{\text {high }}$ Regulatory T Cells Are Overrepresented in Human Metastatic Melanoma Lymph Nodes and Inhibit the Function of Infiltrating T Cells. Journal of Immunology, 173, 1444-1453. http://dx.doi.org/10.4049/jimmunol.173.2.1444

[13] Ormandy, L.A., Hillemann, T., Wedemeyer, H., Manns, M.P., Greten, T.F. and Korangy, F. (2005) Increased Populations of Regulatory T Cells in Peripheral Blood of Patients with Hepatocellular Carcinoma. Cancer Research, 65 2457-1464. http://dx.doi.org/10.1158/0008-5472.CAN-04-3232

[14] Joosten, S.A. and Ottenhoff, T.H.M. (2008) Human CD4 and CD8 Regulatory T Cells in Infectious Diseases and Vaccination. Human Immunology, 69, 760-770. http://dx.doi.org/10.1016/j.humimm.2008.07.017

[15] Bishop, J.M. (1987) The Molecular Genetics of Cancer. Science, 235, 305-311. http://dx.doi.org/10.1126/science.3541204

[16] Whitfield, M.L., George, L.K., Grant, G.D. and Perou, C.M. (2006) Common Markers of Proliferation. Nature Reviews Cancer, 6, 99-106. http://dx.doi.org/10.1038/nrc1802

[17] Dunning, A.M., Healey, C.S., Pharoah, P.D.P., Teare, D.M., Ponder, B.A.J. and Easton, D.F. (1999) A Systematic Review of Genetic Polymorphisms and Breast Cancer Risk. Cancer Epidemiology, Biomarkers \& Prevention, 8, 843-854.

[18] Toru, H., Masaharu, Y., Shinji, T. and Kazuaki, C. (2008) Genetic Polymorphisms and Head and Neck Cancer Risk. International Journal of Oncology, 32, 945-973.

[19] Ignatiadis, M., Xenidis, N., Perraki, M., Apostolaki, S., Politaki, E., Kafousi, M., et al. (2007) Different Prognostic Value of Cytokeratin-19 mRNA Positive Circulating Tumor Cells According to Estrogen Receptor and HER2 Status in Early-Stage Breast Cancer. Journal of Clinical Oncology, 25, 5194-5202. http://dx.doi.org/10.1200/JCO.2007.11.7762

[20] Delys, L., Detours, V., Franc, B., Thomas, G., Bogdanova, T., Tronko, M., et al. (2007) Gene Expression and the Biological Phenotype of Papillary Thyroid Carcinomas. Oncogene, 26, 7894-7903. http://dx.doi.org/10.1038/sj.onc.1210588

[21] Dwarakanath, B.S., Manogaran, P.S., Das, S., Das, B.S. and Jain, V. (1994) Heterogeneity in DNA Content and Proliferative Status of Human Brain Tumors. Indian Journal of Medical Research, 100, 279-286.

[22] Weber, J.L. and May, P.E. (1989) Abundant Class of Human DNA Polymorphisms Which Can Be Typed Using Polymerase Chain Reaction. American Journal of Human Genetics, 44, 388-396.

[23] Arzimanoglou, I.I., Gilbert, F. and Barger, H.R. (1998) Microsatellite Instability in Human Solid Tumors. Cancer, 82, 1808-1820. http://dx.doi.org/10.1002/(SICI)1097-0142(19980515)82:10<1808::AID-CNCR2>3.0.CO;2-J

[24] Arnold, K. (2000) Biomarker for Esophageal Cancer Found in Bloodstream. Journal of the National Cancer Institute, 92, 1787.

[25] Fearnhead, N.S., Britton, M.P. and Bodmer, W.F. (2001) The ABC of APC. Human Molecular Genetics, 10, $721-733$. http://dx.doi.org/10.1093/hmg/10.7.721

[26] Kim, H., Kwon, Y.M., Kim, J.S., Lee, H., Park, J.H., Shim, Y.M., et al. (2004) Tumor-Specific Methylation in Bron- 
chial Lavage for the Early Detection of Non-Small-Cell Lung Cancer. Journal of Clinical Oncology, 22, 2363-2370. http://dx.doi.org/10.1200/JCO.2004.10.077

[27] Ehrlich, M. (2002) DNA Methylation in Cancer: Too Much, but Also Too Little. Oncogene, 21, 5400-5413. http://dx.doi.org/10.1038/sj.onc.1205651

[28] Cuezva, J.M., Krajewska, M., Heredia, M.L., Krajewski, S., Kim, G.S.H., Zapata, J.M., et al. (2002) The Bioenergetic Signature of Cancer: A Marker of Tumor Progression. Cancer Research, 62, 6674-6681.

[29] Reivich, M., Kuhl, D., Wolf, A., Greenberg, J., Phelps, M., Ido, T., et al. (1977) Measurement of Local Cerebral Glucose Metabolism in Man with 18F-2-Fluoro-2-deoxy-D-glucose. Acta neurologica Scandinavica. Supplementum, 64, 190-191.

[30] Dichiro, G., Brooks, R.A., Patronas, N.T., Bairamian, D., Kornblith, P.L., Smith, B.H., et al. (1984) Issues in the in Vivo Measurement of Glucose Metabolism of Human Central Nervous System Tumors. Annals of Neurology, 15, 138146. http://dx.doi.org/10.1002/ana.410150727

[31] Padma, M.V., Said, S., Jacobs, M., Hwang, D.R., Dunigan, K., Satter, M., et al. (2003) Prediction of Pathology and Survival by FDG PET in Gliomas. Journal of Neuro-Oncology, 64, 227-237. http://dx.doi.org/10.1023/A:1025665820001

[32] Spence, A.M., Muzi, M., Graham, M.M., O’Sullivan, F., Link, J.M., Lewellen, T.K., et al. (2002) 2- $\left[{ }^{18}\right.$ F]Fluoro-2-deoxyglucose and Glucose Uptake in Malignant Gliomas before and after Radiotherapy: Correlation with Outcome. Clinical Cancer Research, 8, 971-979.

[33] Weber, W.A. (2006) Positron Emission Tomography as an Imaging Biomarker. Journal of Clinical Oncology, 20, 3282-3292. http://dx.doi.org/10.1200/JCO.2006.06.6068

[34] Stricker, T., Vatenacci, D.V.T. and Seiwert, T.Y. (2011) Molecular Profiling of Cancer-The Future of Personalized Cancer Medicine: A Primer on Cancer Biology and the Tools Necessary to Bring Molecular Testing to the Clinic. Seminars in Oncology, 38, 173-185. http://dx.doi.org/10.1053/j.seminoncol.2011.01.013

[35] Thurlimann, B., Goldhirsch, A., Castiglione, M., Hsu-Schmitz, S.F., Cavalli, F., Bonnefoi, H., et al. (1997) Formestane versus Megestrol Acetate in Postmenopausal Breast Cancer Patients after Failure of Tamoxifen: A Phase III Prospective Randomised Cross over Trial of Second-Line Hormonal Treatment (SAKK 20/90). European Journal of Cancer, 33, 1017-1024.

[36] Stuart, N.S.A., Warwick, J., Blackledge, G.R.P., Spooner, D., Keen, C., Earl, H., et al. (1996) A Randomized Phase III Cross-Over Study of Tamoxifen versus Megestrol Acetate in Advanced and Recurrent Breast Cancer. European Journal of Cancer, 32, 1888-1892.http://dx.doi.org/10.1016/0959-8049(96)00191-8

[37] Cuzick, J. (2007) LHRH-Agonists in Early Breast Cancer Overview Group. Use of Luteinising-Hormone-Releasing Hormone Agonists as Adjuvant Treatment in Premenopausal Patients with Hormone-Receptor-Positive Breast Cancer: A Meta-Analysis of Individual Patient Data from Randomised Adjuvant Trials. The Lancet, 369, 1711-1723. http://dx.doi.org/10.1016/S0140-6736(07)60778-8

[38] Lewis, J.D., Chagpar, A.B., Shaughnessy, E.A., Nurko, J., McMasters, K. and Edwards, M.J. (2010) Excellent Outcomes with Adjuvant Toremifene or Tamoxifen in Early Stage Breast Cancer. Cancer, 116, 2307-2315.

[39] Dowsett, M., Allred, C., Knox, J., Quinn, E., Salter, J., Allred, C., et al. (2008) Relationship between Quantitative Estrogen and Progesterone Receptor Expression and Human Epidermal Growth Factor Receptor 2 (HER-2) Status with Recurrence in the Arimidex, Tamoxifen, Alone or in Combination Trial. Journal of Clinical Oncology, 26, 1059-1065. http://dx.doi.org/10.1200/JCO.2007.12.9437

[40] Bartlett, J.M.S., Rea, D., et al. (2011) Estrogen Receptor and Progesterone Receptor as Predictive Biomarkers of Response to Endocrine Therapy: A Prospectively Powered Pathology Study in the Tamoxifen and Exemestane Adjuvant Multinational Trial. Journal of Clinical Oncology, 29, 1531-1538. http://dx.doi.org/10.1200/JCO.2010.30.3677

[41] Coombes, R.C., Kilburn, L.S., Snowdon, C.F., Paridaens, R., Coleman, R.E., Bliss, J.M., et al. (2007) Survival and Safety of Exemestane versus Tamoxifen after 2-3 Years' Tamoxifen Treatment (Intergroup Exemestane Study): A Randomized Controlled Trial. The Lancet, 369, 559-570.

[42] Viale, G., Regan, M.M., Maiorano, E., Mastropasqua, M.G., Golouh, R., Regan, M.M., et al. (2008) Chemoendocrine Compared with Endocrine Adjuvant Therapies for Node-Negative Breast Cancer: Predictive Value of Centrally Reviewed Expression of Estrogen and Progesterone Receptors-International Breast Cancer Study Group. Journal of Clinical Oncology, 26, 1404-1410. http://dx.doi.org/10.1200/JCO.2007.10.6393

[43] Anderson, H., Hills, M., Zabaglo, L., A’Hern, R., Leary, A.F., Dowsett, M., et al. (2011) Relationship between Estrogen Receptor, Progesterone Receptor, HER-2 and Ki67 Expression and Efficacy of Aromatase Inhibitors in Advanced Breast Cancer. Annals of Oncology, 22, 1770-1776. http://dx.doi.org/10.1093/annonc/mdq700

[44] Stendahl, M., Ryden, L., Nordenskjöld, B., Ebbe Jönsson, P., Landberg, G. and Jirström, K. (2006) High Progesterone Receptor Expression Correlates to the Effect of Adjuvant Tamoxifen in Premenopausal Breast Cancer Patients. Clini- 
cal Cancer Research, 12, 4614-4618. http://dx.doi.org/10.1158/1078-0432.CCR-06-0248

[45] Yamashita, H., Ando, Y., Nishio, M., Zhang, Z., Hamaguchi, M., Mita, K., et al. (2006) Immunohistochemical Evaluation of Hormone Receptor Status for Predicting Response to Endocrine Therapy in Metastatic Breast Cancer. Breast Cancer, 13, 74-83. http://dx.doi.org/10.2325/jbcs.13.74

[46] Yu, Z., Yang, Q., et al. (2005) Thymidylate Synthase Predicts for Clinical Outcome in Invasive Breast Cancer. Histology and Histopathology, 20, 871-878.

[47] Chen, C.Y., Yang, P.C., et al. (2011) Thymidylate Synthase and Dihydrofolate Reductase Expression in Non-Small Cell Lung Carcinoma: The Association with Treatment Efficacy of Pemetrexed. Lung Cancer, 74, 132-138. http://dx.doi.org/10.1016/j.lungcan.2011.01.024

[48] Lee, S.J., Im, Y.H., et al. (2011) Thymidylate Synthase and Thymidine Phosphorylase as Predictive Markers of Capecitabine Monotherapy in Patients with Anthracycline- and Taxane-Pretreated Metastatic Breast Cancer. Cancer Chemotherapy and Pharmacology, 68, 743-751. http://dx.doi.org/10.1007/s00280-010-1545-0

[49] Penson, R.T., Seiden, M.V., et al. (2004) Expression of Multidrug Resistance-1 Protein Inversely Correlates with Paclitaxel Response and Survival in Ovarian Cancer Patients: A Study in Serial Samples. Gynecologic Oncology, 93, 98106. http://dx.doi.org/10.1016/j.ygyno.2003.11.053

[50] Yeh, J.J., Hsu, W.H., Wang, J.J., Ho, S.T. and Kao, A. (2003) Predicting Chemotherapy Response to Paclitaxel-Based Therapy in Advanced Non-Small-Cell Lung Cancer with P-Glycoprotein Expression. Respiration, 70, 32-35. http://dx.doi.org/10.1159/000068411

[51] Von Hoff, D.D., Hidalgo, M., et al. (2011) Gemcitabine Plus nab-Paclitaxel Is an Active Regimen in Patients with Advanced Pancreatic Cancer: A Phase I/II Trial. Journal of Clinical Oncology, 29, 4548-4554. http://dx.doi.org/10.1200/JCO.2011.36.5742

[52] Desai, N., Trieu, V., Damascelli, B. and Soon-Shiong, P. (2009) SPARC Expression Correlates with Tumor Response to Albumin-Bound Paclitaxel in Head and Neck Cancer Patients. Translational Oncology, 2, 59-64. http://dx.doi.org/10.1593/tlo.09109

[53] Seve, P., Dumontet, C., et al. (2005) Class III $\beta$-Tubulin Expression in Tumor Cells Predicts Response and Outcome in Patients with Non-Small Cell Lung Cancer Receiving Paclitaxel. Molecular Cancer Therapeutics, 4, 2001-2007. http://dx.doi.org/10.1158/1535-7163.MCT-05-0244

[54] Ploussard, G., de la Taille, A., et al. (2010) Class III $\beta$-Tubulin Expression Predicts Prostate Tumor Aggressiveness and Patient Response to Docetaxel-Based Chemotherapy. Clinical Cancer Research, 70, 9253-9264.

[55] Gao, S., Zhao, X., Lin, B., Hu, Z., Yan, L. and Gao, J. (2012) Clinical Implications of REST and TUBB 3 in Ovarian Cancer and Its Relationship to Paclitaxel Resistance. Tumor Biology, 33, 1759-1765. http://dx.doi.org/10.1007/s13277-012-0435-y

[56] Zhang, H.L., Ruan, L., Zheng, L-M., Whyte, D., Tzeng, C-M. and Zhou, X.W. (2012) Association between Class III $\beta$-Tubulin Expression and Response to Paclitaxel/Vinorelbine-Based Chemotherapy for Non-Small Cell Lung Cancer: A Meta-Analysis. Lung Cancer, 77, 9-15. http://dx.doi.org/10.1016/j.lungcan.2012.01.005

[57] Kulkarni, S.A., Ross, D.T., et al. (2009) TLE3 as a Candidate Biomarker of Response to Taxane Therapy. Breast Cancer Research, 11, R17. http://dx.doi.org/10.1186/bcr2241

[58] Gong, W., Dong, J., et al. (2012) RRM $\mathrm{R}_{1}$ Expression and Clinical Outcome of Gemcitabine-Containing Chemotherapy for Advanced Non-Small-Cell Lung Cancer: A Meta-Analysis. Lung Cancer, 75, 374-380. http://dx.doi.org/10.1016/j.lungcan.2011.08.003

[59] Ataka, M., Katano, K., et al. (2007) Topoisomerase I Protein Expression and Prognosis of Patients with Colorectal Cancer. Yonago Acta Medica, 50, 81-87.

[60] Braun, M.S., Seymour, M.T., et al. (2008) Predictive Biomarkers of Chemotherapy Efficacy in Colorectal Cancer: Results from the UK MRC FOCUS Trial. Journal of Clinical Oncology, 26, 2690-2698. http://dx.doi.org/10.1200/JCO.2007.15.5580

[61] Kostopoulos, I., Fountzilas, G., et al. (2009) Topoisomerase I but Not Thymidylate Synthase Is Associated with Improved Outcome in Patients with Resected Colorectal Cancer Treated with Irinotecan Containing Adjuvant Chemotherapy. BMC Cancer, 9, 339. http://dx.doi.org/10.1186/1471-2407-9-339

[62] Baselga, J., Swain, S.M., et al. (2012) Pertuzumab Plus Trastumab Plus Docetaxel for Metastatic Breast Cancer. The New England Journal of Medicine, 36, 109-119. http://dx.doi.org/10.1056/NEJMoa1113216

[63] National Comprehensive Cancer Network (2013) NCCN Clinical Practice Guidelines in Oncology. Breast Cancer Version 2.2013

[64] Bachelot, T., Pujade-Lauraine, E., et al. (2012) Randomized Phase II Trial of Everolimus in Combination with Tamoxifen in Patients with Hormone Receptor-Positive, Human Epidermal Growth Factor Receptor 2-Negative Metastatic Breast Cancer with Prior Exposure to Aromatase Inhibitors: A GINECO Study. Journal of Clinical Oncology, 30, 
2718-2724 http://dx.doi.org/10.1200/JCO.2011.39.0708

[65] Wolff, A.C., Hayes, D.F., et al. (2013) Recommendations for Human Epidermal Growth Factor Receptor 2 Testing in Breast Cancer: American Society of Clinical Oncology/College of American Pathologists Clinical Practice Guideline Update. Journal of Clinical Oncology, 31, 3997-4013. http://dx.doi.org/10.1200/JCO.2013.50.9984

[66] Janku, F., Kurzrock, R., et al. (2012) PI3K/AKT/mTOR Inhibitors in Patients with Breast and Gynecologic Malignancies Harboring PIK3CA Mutations. Journal of Clinical Oncology, 30, 777-782. http://dx.doi.org/10.1200/JCO.2011.36.1196

[67] Janku, F., Kurzrock, R., et al. (2012) PIK3CA Mutation H1047R Is Associated with Response to PI3K/AKT/mTOR Signaling Pathway Inhibitors in Early-Phase Clinical Trials. Cancer Research, 73, 276-284. http://dx.doi.org/10.1158/0008-5472.CAN-12-1726

[68] Moroney, J.W., Kurzrock, R., et al. (2011) A Phase I Trial of Liposomal Doxorubicin, Bevacizumab, and Temsirolimus in Patients with Advanced Gynecologic and Breast Malignancies. Clinical Cancer Research, 17, 6840-6846. http://dx.doi.org/10.1158/1078-0432.CCR-11-0666

[69] Guo, J., Qin, S., et al. (2011) Phase II, Open-Label, Single-Arm Trial of Imatinib Mesylate in Patients with Metastatic Melanoma Harboring c-Kit Mutation or Amplification. Journal of Clinical Oncology, 29, 2904-2909. http://dx.doi.org/10.1200/JCO.2010.33.9275

[70] Carvajal, R.D., Schwartz, G.K., et al. (2011) KIT as a Therapeutic Target in Metastatic Melanoma. Journal of the American Medical Association, 305, 2327-2334. http://dx.doi.org/10.1001/jama.2011.746

[71] Debiec-Rychter, M., Judson, I., et al. (2006) KIT Mutations and Dose Selection for Imatinib in Patients with Advanced Gastrointestinal Stromal Tumours. European Journal of Cancer, 42, 1093-1103. http://dx.doi.org/10.1016/j.ejca.2006.01.030

[72] Heinrich, M.C., Fletcher, J.A., et al. (2008) Correlation of Kinase Genotype and Clinical Outcome in North American Intergroup Phase III Trial of Imatinib Mesylate for Treatment of Advanced Gastrointestinal Stromal Tumor: CALGB 150105 Study by Cancer and Leukemia Group B and Southwest Oncology Group. Journal of Clinical Oncology, 26, 5360-5367. http://dx.doi.org/10.1200/JCO.2008.17.4284

[73] Cassier, P.A., Hohenberger, P., et al. (2012) Outcome of Patients with Platelet-Derived Growth Factor Receptor Alpha-Mutated Gastrointestinal Stromal Tumors in the Tyrosine Kinase Inhibitor Era. Clinical Cancer Research, 18, 4458-4464. http://dx.doi.org/10.1158/1078-0432.CCR-11-3025

[74] Wells, S.A., Schlumberger, M.J., et al. (2012) Vandetanib in Patients with Locally Advanced or Metastatic Medullary Thyroid Cancer: A Randomized, Double-Blind Phase III Trial. Journal of Clinical Oncology, 30, 134-141. http://dx.doi.org/10.1200/JCO.2011.35.5040

[75] Gennari, A., Bruzzi, P., et al. (2008) $H E R_{2}$ Status and Efficacy of Adjuvant Anthracyclines in Early Breast Cancer: A Pooled Analysis of Randomized Trials. Journal of the National Cancer Institute, 100, 14-20. http://dx.doi.org/10.1093/jnci/djm252

[76] Press, M.F., Slamon, D.J., et al. (2011) Alteration of Topoisomerase II-Alpha Gene in Human Breast Cancer: Association with Responsiveness to Anthracycline Based Chemotherapy. Journal of Clinical Oncology, 29, 859-867. http://dx.doi.org/10.1200/JCO.2009.27.5644

[77] Akimoto, M., Saisho, H., et al. (2006) Relationship between Therapeutic Efficacy of Arterial Infusion Chemotherapy and Expression of P-Glycoprotein and p53 Protein in Advanced Hepatocellular Carcinoma. World Journal of Gastroenterology, 12, 868-873.

[78] Mittal, M.K., Singh, J.P., et al. (2005) Role of p-Glycoprotein Expression in Predicting Response to Neoadjuvant Chemotherapy in Breast Cancer-A Prospective Clinical Study. World Journal of Surgical Oncology, 3, 61. http://dx.doi.org/10.1186/1477-7819-3-61

[79] O’Malley, F.P., Pritchard, K.I., et al. (2011) Topoisomerase II Alpha Protein and Responsiveness of Breast Cancer to Adjuvant Chemotherapy with CEF Compared to CMF in the NCIC CTG Randomized MA.5 Adjuvant Trial. Breast Cancer Research and Treatment, 128, 401-409. http://dx.doi.org/10.1007/s10549-011-1511-5

[80] Rodrigo, R.S., Axel L.C., et al. (2011) Topoisomerase II-Alpha Protein Expression and Histological Response Following Doxorubicin-Based Induction Chemotherapy Predict Survival of Locally Advanced Soft Tissues Sarcomas. European Journal of Cancer, 47, 1319-1327. http://dx.doi.org/10.1016/j.ejca.2011.02.010

[81] Buckingham, L.P., Bonomi, P., et al. (2007) The Prognostic Value of Chromosome 7 Polysomy in Non-Small Cell Lung Cancer Patients Treated with Gefitinib. Journal of Thoracic Oncology, 2, 414-422. http://dx.doi.org/10.1097/01.JTO.0000268675.02744.b0

[82] Verma, S., Blackwell, K., et al. (2012) Trastuzumab Emtansine for HER2-Positive Advanced Breast Cancer. The New England Journal of Medicine, 367, 1783-1791. http://dx.doi.org/10.1056/NEJMoa1209124

[83] Cortes, J., Baselga, J., et al. (2012) Pertuzumab Monotherapy after Trastuzumab-Based Treatment and Subsequent 
Reintroduction of Trastuzumab: Activity and Tolerability in Patients with Advanced Human Epidermal Growth Factor Receptor 2-Positive Breast Cancer. Journal of Clinical Oncology, 30, 1594-1600.

http://dx.doi.org/10.1200/JCO.2011.37.4207

[84] Bang, Y.J., Kang, Y.K., et al. (2010) Trastuzumab in Combination with Chemotherapy versus Chemotherapy Alone for Treatment of HER2-Positive Advanced Gastric or Gastro-Oesophageal Junction Cancer (ToGA): A Phase 3, OpenLabel, Randomised Controlled Trial. The Lancet, 376, 687-697.

http://dx.doi.org/10.1016/S0140-6736(10)61121-X

[85] Yin, W., Jiang, Y., Shen, Z., Shao, Z. and Lu, J. (2011) Trastuzumab in the Adjuvant Treatment of HER2-Positive Early Breast Cancer Patients: A Meta-Analysis of Published Randomized Controlled Trials. PLoS ONE, 6, e21030. http://dx.doi.org/10.1371/journal.pone.0021030

[86] Slamon, D., Buyse, M., et al. (2011) Adjuvant Trastuzumab in HER2-Positive Breast Cancer. The New England Journal of Medicine, 365, 1273-1283. http://dx.doi.org/10.1056/NEJMoa0910383

[87] Hurvitz, S.A., Perez, E.A., et al. (2013) Phase II Randomized Study of Trastuzumab Emtansine versus Trastuzumab plus Docetaxel in Patients with Human Epidermal Growth Factor Receptor 2-Positive Metastatic Breast Cancer. Journal of Clinical Oncology, 31, 1157-1163. http://dx.doi.org/10.1200/JCO.2012.44.9694

[88] Johnston, S., Pegram, M., et al. (2009) Lapatinib Combined with Letrozole versus Letrozole and Placebo as First-Line Therapy for Postmenopausal Hormone Receptor-Positive Metastatic Breast Cancer. Journal of Clinical Oncology, 27, 5538-5546. http://dx.doi.org/10.1200/JCO.2009.23.3734

[89] Amir, E., Ocaña, A., Seruga, B., Freedman, O. and Clemons, M. (2010) Lapatinib and HER2 Status: Results of a Meta-Analysis of Randomized Phase III Trials in Metastatic Breast Cancer. Cancer Treatment Reviews, 36, 410-415. http://dx.doi.org/10.1016/j.ctrv.2009.12.012

[90] Press, M.F., Finn, R.S., et al. (2008) HER-2 Gene Amplification, HER-2 and Epidermal Growth Factor Receptor mRNA and Protein Expression, and Lapatinib Efficacy in Women with Metastatic Breast Cancer. Clinical Cancer Research, 14, 7861-7870. http://dx.doi.org/10.1158/1078-0432.CCR-08-1056

[91] Chinot, O.L., Barrie, M., et al. (2007) Correlation between $\mathrm{O}^{6}$-Methylguanine-DNA Methyltransferase and Survival in Inoperable Newly Diagnosed Glioblastoma Patients Treated with Neoadjuvant Temozolomide. Journal of Clinical Oncology, 25, 1470-1475. http://dx.doi.org/10.1200/JCO.2006.07.4807

[92] Busch, C., Geislerd, J., Lillehaug, J.R. and Lønning, P.E. (2010) MGMT Expression Levels Predict Disease Stabilisation, Progression-Free and Overall Survival in Patients with Advanced Melanomas Treated with DTIC. European Journal of Cancer, 46, 2127-2133. http://dx.doi.org/10.1016/j.ejca.2010.04.023

[93] Warburg, O. (1923) Metabolism of Tumours. Biochemische Zeitschrift, 142, 317-333.

[94] Warburg, O. (1925) Iron, the Oxygen-Carrier of Respiration-Ferment. Science, 61, 575-582. http://dx.doi.org/10.1126/science.61.1588.575

[95] Racker, E. (1972) Bioenergetics and the Problem of Tumor Growth. American Scientist, 60, 56-63.

[96] Turner, J.S. and Brittain, E.G. (1962) Oxygen as a Factor in Photosynthesis. Biological Reviews, 37, 130-170. http://dx.doi.org/10.1111/j.1469-185X.1962.tb01607.x

[97] Lee, C., Raffaghello, L., Brandhorst, S., Safdie, F.M., Bianchi, G., Martin-Montalvo, A., Pistoia, V., Wei, M., Hwang, S., Merlino, A., Emionite, L., Cabo, R. and Longo, V. (2012) Fasting Cycles Retard Growth of Tumor and Sensitize a Range of Cancer Cell Types to Chemotherapy. Science Translational Medicine, 4, 124-127.

[98] Cushman, S.W. and Wardzala, L.J. (1980) Potential Mechanism of Insulin Action on Glucose Transport in the Isolated Rat Adipose Cell. Apparent Translocation of Intracellular Transport Systems to the Plasma Membrane. Journal of Biological Chemistry, 255, 4758-4762.

[99] Suzuki, K. and Kono, T. (1980) Evidence That Insulin Causes Translocation of Glucose Transport Activity to the Plasma Membrane from an Intracellular Storage Site. Proceedings of the National Academy of Sciences of the United States of America, 77, 2542-2545. http://dx.doi.org/10.1073/pnas.77.5.2542

[100] Papa, V., Pezzino, V., Costantino, A., Belfiore, A., Giuffrida, D., Frittitta, L., Vannelli, G.B., Brand, R., Goldfine, I.D. and Vigneri, R. (1990) Elevated Insulin Receptor Content in Human Breast Cancer. Journal of Clinical Investigation, 86, 1503-1510. http://dx.doi.org/10.1172/JCI114868

[101] Belfiore, A. (2007) The Role of Insulin Receptor Isoforms and Hybrid Insulin/IGF-I Receptors in Human Cancer. Current Pharmaceutical Design, 13, 671-686. http://dx.doi.org/10.2174/138161207780249173

[102] Grana, X. and Reddy, E.P. (1995) Cell Cycle Control in Mammalian Cells: Role of Cyclins, Cyclin Dependent Kinases (CDKs), Growth Suppressor Genes and Cyclin-Dependent Kinase Inhibitors (CKIs). Oncogene, 11, 211-219.

[103] Johnson, D.G. and Walker, C.L. (1999) Cyclins and Cell Cycle Checkpoints. Annual Review of Pharmacology and Toxicology, 39, 295-312. http://dx.doi.org/10.1146/annurev.pharmtox.39.1.295 
[104] Kaldis, P., Russo, A.A., Chou, H.S., Pavletich, N.P. and Solomon, M.J. (1998) Human and Yeast Cdk-Activating Kinases (CAKs) Display Distinct Substrate Specificities. Molecular Biology of the Cell, 9, 2545-2560. http://dx.doi.org/10.1091/mbc.9.9.2545

[105] Hartwell, L.H. and Kastan, M.B. (1994) Cell Cycle Control and Cancer. Science, 266, 1821-1828. http://dx.doi.org/10.1126/science.7997877

[106] Harper, J. and Elledge, S.J. (1996) Cdk Inhibitors in Development and Cancer. Current Opinion in Genetics \& Development, 6, 56-64. http://dx.doi.org/10.1016/S0959-437X(96)90011-8

[107] Senderowicz, A.M. (2002) Cyclin-Dependent Kinases as Targets for Cancer Therapy. In: Giaccone, G., Schilsky, R. and Sondel. P., Eds., Cancer Chemotherapy and Biological Response Modifiers Annual 20, Elsevier Science, New York, 169-188.

[108] Gliozzo, B., Sung, C.K., Scalia, P.L., Papa, V., Frasca, F., Sciacca, L., Giorgino, F., Milazzo, G., Goldfine, I.D., Vigneri, R. and Pezzino, V.J. (1998) Insulin-Stimulated Cell Growth in Insulin Receptor Substrate-1-Deficient ZR-75-1 Cells Is Mediated by a Phosphatidylinositol-3-Kinase-Independent Pathway. Journal of Cellular Biochemistry, 70, 268-280. http://dx.doi.org/10.1002/(SICI)1097-4644(19980801)70:2<268::AID-JCB12>3.0.CO;2-J

[109] Bentel, J.M., Lebwohl, D.E., Cullen, K.J., Rubin, M.S., Rosen, N., Mendelsohn, J. and Miller, W.H. (1995) Insulin-Like Growth Factors Modulate the Growth Inhibitory Effects of Retinoic Acid on MCF-7 Breast Cancer Cells. Journal of Cellular Physiology, 165, 212-221. http://dx.doi.org/10.1002/jcp.1041650124

[110] Yang, X.F., Beamer, W.G., Huynh, H.T. and Pollak, M. (1996) Cancer Research, 56, 1509-1511.

[111] Pollak, M., Constantino, J., Polychronakos, C., Blauer, S.A., Guyda, H., Redmond, C., Fisher, B. and Margolese, R. (1990) Effect of Tamoxifen on Serum Insulinlike Growth Factor I Levels in Stage I Breast Cancer Patients. Journal of the National Cancer Institute, 82, 1693-1697. http://dx.doi.org/10.1093/jnci/82.21.1693

[112] Milazzo, G., Giorgino, F., Damante, G., Sung, C., Stampfer, M.R., Vigneri, R., Goldfine, I. and Belfiore, A. (1992) Cancer Research, 52, 3924-3930.

[113] Frittitta, L., Vigneri, R., Stampfer, M.R. and Goldfine, I.D.J. (1995) Insulin Receptor Overexpression in 184B5 Human Mammary Epithelial Cells Induces a Ligand-Dependent Transformed Phenotype. Journal of Cellular Biochemistry, 57, 666-669. http://dx.doi.org/10.1002/jcb.240570411

[114] Kaleko, M., Rutter, W.J. and Miller, A.D. (1990) Molecular and Cellular Biology, 10, 464-473.

[115] Mountjoy, K.G., Finlay, G.J. and Holdaway, I.M. (1987) Cancer Research, 47, 6500-6504.

[116] Benson, E.A. and Holdaway, I.M. (1982) Cancer Research, 42, 1137-1141.

[117] Belfiore, A., Frittitta, L., Costantino, A., Frasca, F., Pandini, G., Sciacca, L., Goldfine, I.D. and Vigneri, R. (1996) Insulin Receptors in Breast Cancer. Annals of the New York Academy of Sciences, 784, 173-188. http://dx.doi.org/10.1111/j.1749-6632.1996.tb16235.x

[118] Chappell, J., Leitner, W., Solomon, S., Golovchenko, I., Goalstone, M.L. and Draznin, B. (2001) Effect of Insulin on Cell Cycle Progression in MCF-7 Breast Cancer Cells. Journal of Biological Chemistry, 41, 38023-38028.

[119] Reyman, P. (1997) Chemotherapy Principles of Administration. In: Groenwald, S.L., Yarbro, C.H., Goodman, M. and Frogge, M.H., Eds., Cancer Nursing Principles and Practice, 4th Edition.

[120] Dorr, R.T. and Vonn Hoff, D.D. (1993) Cancer Chemotherapy Handbook. 2nd Edition. Appleton \& Lange, Norwalk.

[121] Schilsky, R.L., Bailey, B.D. and Chabner, B.A. (1981) Characteristics of Membrane Transport of Methotrexate by Cultured Human Breast Cancer Cells. Biochemical Pharmacology, 30, 1537-1542. http://dx.doi.org/10.1016/0006-2952(81)90378-6

[122] Lippman, M., Bolan, G. and Huff, K. (1976) The Effects of Estrogens and Antiestrogens on Hormone-Responsive Human Breast Cancer in Long-Term Tissue Culture. Cancer Research, 36, 4595-4601.

[123] Monaco, M.E. and Lippman, M.E. (1977) Insulin Stimulation of Fatty Acid Synthesis in Human Breast Cancer in Long Term Tissue Culture. Endocrinology, 101, 1238-1246. http://dx.doi.org/10.1210/endo-101-4-1238

[124] Plich, P.F., Thompson, P.A. and Czech, M.P. (1980) Coordinate Modulation of D-Glucose Transport Activity and Bilayer Fluidity in Plasma Membranes Derived from Control and Insulin-Treated Adipocytes. Proceedings of the National Academy of Sciences of the United States of America, 77, 915-918. http://dx.doi.org/10.1073/pnas.77.2.915

[125] Snyder, A.L., Kann, H.E. and Kohn, K.W. (1971) Inhibition of the Processing of Ribosomal Precursor RNA by Intercalating Agents. Journal of Molecular Biology, 58, 555-565. http://dx.doi.org/10.1016/0022-2836(71)90371-8

[126] Tobey, R.A. (1972) A Simple, Rapid Technique for Determination of the Effects of Chemotherapeutic Agents on Mammalian Cell Cycle Traverse. Cancer Research, 32, 309-316.

[127] Paoletti, C., Lesca, C., Cros, S., Mahy, C. and Auclairs, C. (1979) Ellipticine and Derivateves Induce Breakage of L1210 Cells DNA in Vitro. Biochemical Pharmacology, 28, 345-350. http://dx.doi.org/10.1016/0006-2952(79)90096-0 
[128] Bhuyan, B.K., Faser, T.J. and Li, L.H. (1972) Cell Cycle Phase Specificity and Biochemical Effects of Ellipticine on Mammalian Cells. Cancer Research, 32, 2538-2544.

[129] Saucier, J.M., Festy, B. and Lepecq, J.B. (1971) The Change of Torsion of the DNA Helix Caused by Intercalation. II. Measurement of the Relative Change of Torsion Induced by Various Intercalating Drugs. Biochimie, 53, 973-980. http://dx.doi.org/10.1016/S0300-9084(71)80065-2

[130] Festy, B., Poisson, J. and Paolettic, C. (1975) A New DNA Intercalating Drug: Methoxy-9-Ellipticine to DNA. Cancer Research, 35, 71-76.

[131] Oster, J.B. and Creasey, W.A. (1981) Enhancement of Cellular Uptake of Ellipticine by Insulin Preincubation. European Journal of Cancer and Clinical Oncology, 17, 1097-1103. http://dx.doi.org/10.1016/0014-2964(81)90294-2

[132] Ohnuma, T. and Holland, J.F. (1997) Nutritional Consequences of Cancer Chemo Therapy and Immunotherapy. Cancer Research, 37, 2395-2406.

[133] Shamberger, R.C., Brennan, M.F., Goodgame, J.T., Lowry, S.F., Maher, M.M., Wesley, R.A. and Pizzo, P.A. (1984) A Prospective Randomized Study of Adjuvant Parenteral Nutrition in the Treatment of Sarcomas: Results of Survival and Metabolic Studies. Surgery, 96, 1-13.

[134] Peacock, J.L., Gorschboth, C.M. and Northon, J.A. (1987) Impact of Insulin on Doxorubicin Induced Rat Host Toxicity and Tumor Regression. Cancer Research, 47, 4318-4322.

[135] Chabner, B.A. and Meyers, C.E. (1985) Clinical Pharmacology of Cancer Chemo Therapy. In: DeVita, V.T., Hellman, S. and Rosenberg, S.A., Eds., Cancer, Principles and Practice of Oncology, J.B. Lippincott Company, Philadelphia, 312.

[136] Kafka, M.S. (1974) The Effect of Insulin on the Permeability of Phosphatidyl Choline Bimolecular Membranes to Glucose. Journal of Membrane Biology, 18, 81-94. http://dx.doi.org/10.1007/BF01870104 
Scientific Research Publishing (SCIRP) is one of the largest Open Access journal publishers. It is currently publishing more than 200 open access, online, peer-reviewed journals covering a wide range of academic disciplines. SCIRP serves the worldwide academic communities and contributes to the progress and application of science with its publication.

Other selected journals from SCIRP are listed as below. Submit your manuscript to us via either submit@scirp.org or Online Submission Portal.
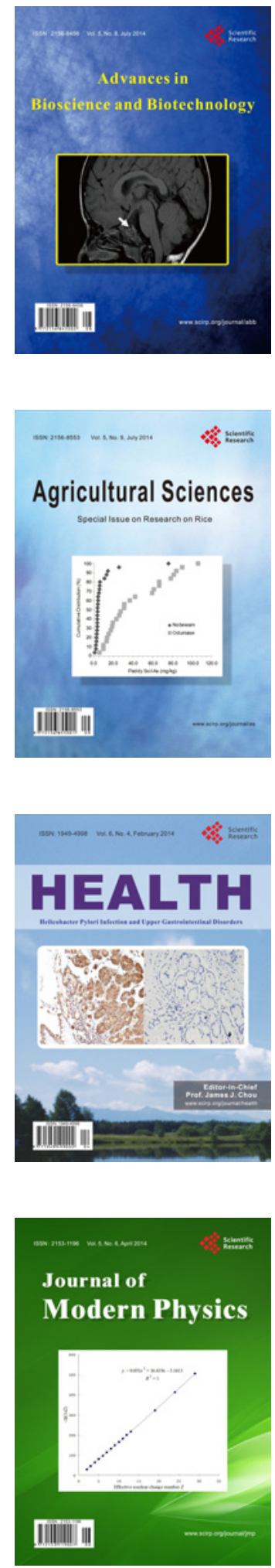
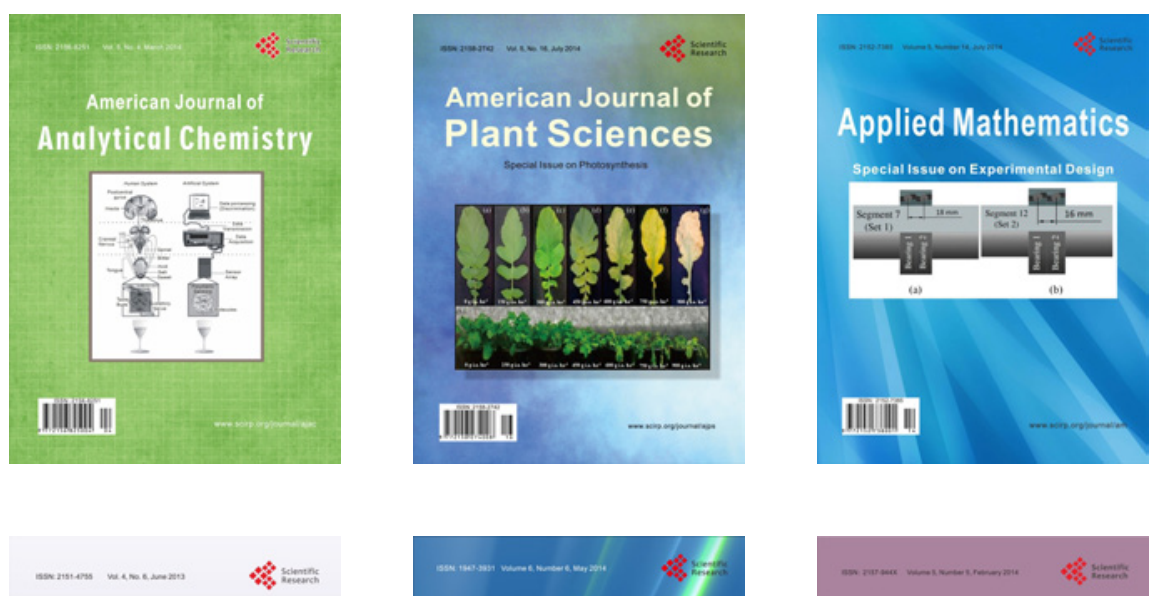

Creative Education
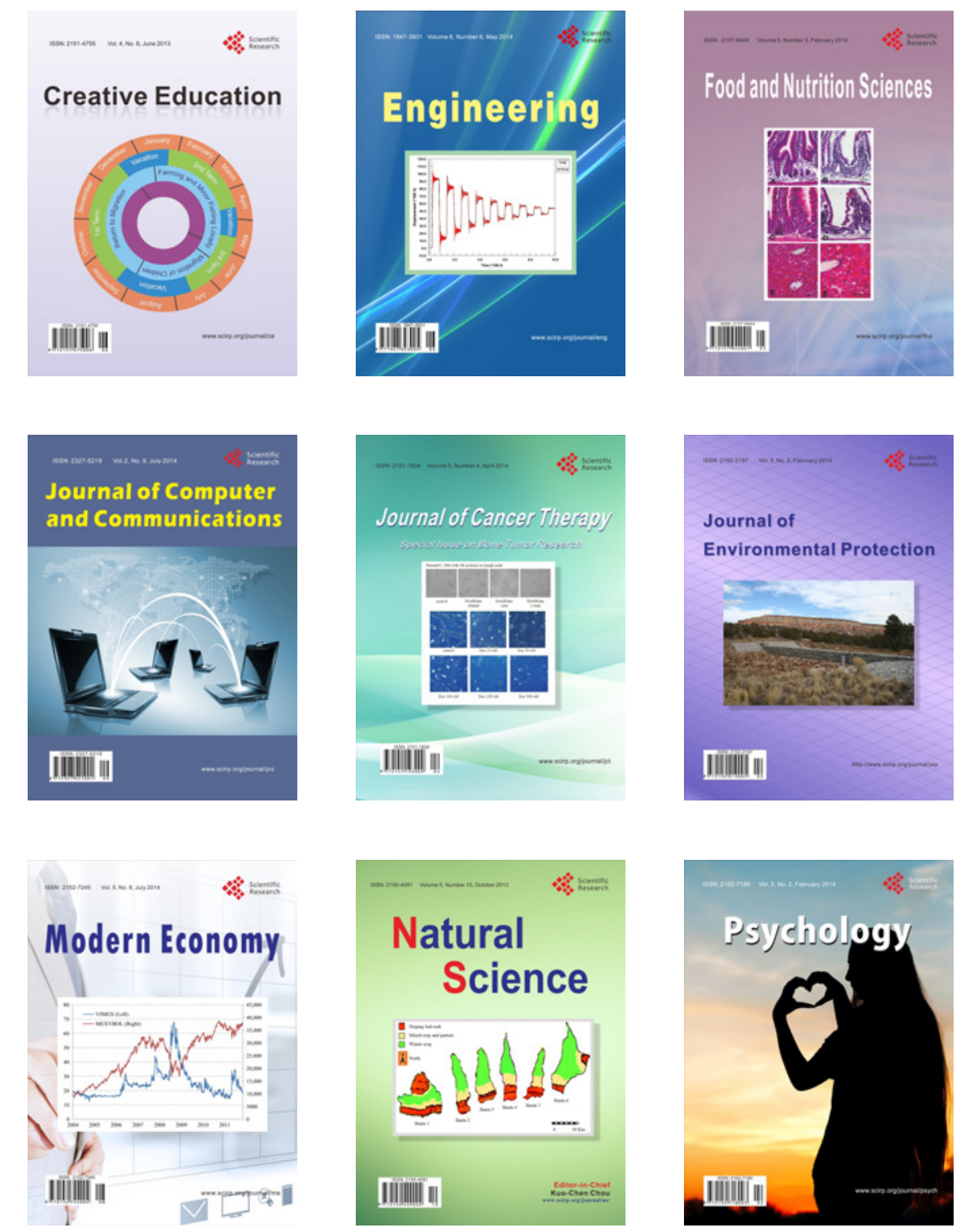